\title{
TECHNICAL AND ECONOMIC ANALYSIS OF IRRIGATION, FERTIGATION AND PLASTIC COVER ON THE TABLE GRAPE 'ITÁLIA' IN THE SERRA GAÚCHA, STATE OF RIO GRANDE DO SUL, BRAZIL
}

\author{
Rodrigo Otávio Câmara Monteiro ${ }^{1}$, Priscylla Ferraz Câmara Monteiro ${ }^{2}$ \\ ${ }^{1}$ Instituto Federal de Educação, Ciência e Tecnologia do Rio Grande do Sul (IFRS-BG), Bento Gonçalves-RS, e-mail: \\ rodrigo.monteiro@bento.ifrs.edu.br \\ ${ }^{2}$ Fundação Estadual de Pesquisa Agropecuária (FEPAGRO), Vacaria, RS, e-mail: priscylla-monteiro@ fepagro.rs.gov.br
}

\section{ABSTRACT}

Recent drought periods in the Serra Gaúcha Region have triggered farmers' interest in adopting irrigation (IS) and fertigation systems (FES).There is little technical information regarding irrigation features and management, high price variation, variety of irrigation equipment brands and their useful life, and there is little technical and economic irrigation data to assist farmers. The objective of the present study was to study the technical and economic feasibility of irrigation, fertigation and plastic cover for the table grape cultivar 'Itália' vineyards in the Serra Gaúcha region, considering climatic conditions and irrigation systems used. For technical and economic feasibility of IS and FES installation in the 'Italy' table grape vine yards under plastic cover in the Serra Gaúcha region there must be a productivity increase from $29 \%$ (IS low cost, long useful life and installed in the plant production stability phase) to 53.7\% (FES automated, short useful life and installed in the first year of growing crop phase).

Keywords: economic feasibility, irrigation system useful life, cost, yield

\section{ANÁLISE TÉCNICO-ECONÔMICA DA IRRIGAÇÃO, DA FERTIRRIGAÇÃO E DA COBERTURA PLÁSTICA NA UVA DE MESA 'ITÁLIA' NA SERRA GAÚCHA, BRASIL}

\section{RESUMO}

Períodos recentes de estiagem na Serra Gaúcha têm incentivado os fruticultores a se interessarem pela adoção de sistemas de irrigação (SI) e fertirrigação (SFE). A falta de informação técnica confiável quanto as características e funcionalidades dos sistemas, a alta variação nos preços dos equipamentos, a diversidade de equipamentos, o desconhecimento da qualidade e da vida útil dos mesmos e a falta de dados técnico-econômicos que auxiliem na decisão de adquirir um sistema de irrigação ou não, tem dificultado a escolha e a decisão dos fruticultores. Este trabalho se propõe a realizar um estudo da viabilidade técnico-econômica do emprego da irrigação, da fertirrigação e da cobertura plástica em pomares de uva de mesa da cultivar Itália na região da Serra Gaúcha, considerando as características regionais produtivas, as condições climáticas e os sistemas de irrigação utilizados. Para a viabilidade técnico-econômica da implantação de SI ou SFE no cultivo de uva de mesa Itália com cobertura plástica na região da Serra Gaúcha é necessário um acréscimo de produtividade de 29\% (SI de baixo custo, vida útil prolongada e instalado quando a cultura está na estabilidade de produção) a 53,7\% (SFE automatizado, curta vida útil e instalado no primeiro ano produtivo da cultura).

Palavras-chave: viabilidade econômica, vida útil, custo, produtividade 


\section{INTRODUCTION}

Irrigation and fertigation have been used in different regions of the world in grape production and the study of irrigation systems, management, and especially economic viability, have become increasingly intense and necessary, as in Turkey (OZKAN et al., 2006), South Africa (WILSON, 2001), India (NAMARA et al., 2007), Italy (EZZHAOUANI et al., 2007) and California, USA (CARPIO \& NESMITH, 2006).

In Brazil, in arid and semi-arid areas such as the San Francisco basin, irrigation and fertigation are fundamental to the table grape production process. Modern table grape farms require more intensive irrigation / fertigation than wine grapes, due to the use of conduction systems designed to accommodate a large leaf area for increased yield. In this region there are several studies on irrigation and fertigation in viticulture (VILELA et al., 2004; TEIXEIRA et al., 2007; MANETA et al., 2009).

In more humid regions such as the Serra Gaúcha, irrigation is applied to supplement the rainfall. In this region the grape finds a favorable climate for its development, but the water supply is important for better quality yield and greater consistency. The table grape yield in this region is almost entirely carried out in environmentally protected systems with plastic cover. These cropping systems provide different microclimatic conditions comparable to natural conditions (CHAVARRIA et al., 2009a; CHAVARRIA et al., 2009b; MOTA et al., 2008). Rainfall interception by plastic cover and changes in temperature and relative humidity under the plastic cover stress the need to establish irrigation systems in these conditions.

Recent drought periods in Rio Grande do Sul state, particularly in the Serra Gaúcha, along with concerns about water supply, have encouraged farmers to adopt localized irrigation systems and fertigation. The lack of research studies on water demand, frequency of water and fertilizer application, among others, in an environmentally protected system along with a lack of reliable technical information regarding the system features, great variation in equipment prices, variety of equipment, lack of equipment quality and useful life and the lack of technical and economic data to assist in the decision whether to purchase an irrigation system has hindered the choice and the decision of the fruit growers. Irrigation and fertigation technology are factors that require high initial investment, have high operating costs due to spending on energy for pumping water and, in some cases, expenses with skilled labor for maintenance and operation of some equipment.

Publications and reports obtained directly from producers about the yield gains provided by irrigation and fertigation in table grape orchards are very encouraging, but the cost / benefit should be analyzed to prevent frustrations of a financial nature. Therefore, the objective of the present study was to investigate the economic viability of irrigation, fertigation and plastic cover in orchards of the 'Italia' table grape cultivar in the Serra Gaúcha region considering the regional characteristics of production, climatic conditions and irrigation system.

\section{MATERIALS AND METHODS}

For the economic viability analysis, we worked with mean values obtained from the fruit growers and EMATER-RS technicians in the main producing regions of the 'Itália' table grape in the Serra Gaúcha, such as Bento Gonçalves, Caxias do Sul and Farroupilha, shown in Tables 1 and 2.

It was considered that the use of irrigation, fertigation and plastic cover in 'Itália' table grape cropping would only be viable if the yield increase was sufficient to generate a net revenue increase greater than 
the annual cost of the project. Therefore, this increase was calculated by:

$$
I P=\left(P c i \times P C S^{-1} \times 100\right)-100(1)
$$

where $I P$ is the yield increase necessary to enable the use of irrigation or fertigation under plastic cover, \%,Pci is yield irrigated or fertigated under plastic cover, $\mathrm{Mg} \mathrm{ha}^{-1}$ year $^{-1}$, Pcs is yield in the first productive years of growing (3-6 years cultivation) no irrigation, no fertigation and without plastic cover, $\mathrm{Mg} \mathrm{ha}^{-1}$ year $^{-1}$.

Table 1. Average data of the irrigation project in 'Itália' table grapes used in the economic feasibility study.

\begin{tabular}{lcc}
\hline Irrigation System (IS) and Fertigation Characterization & Unit $^{-1}$ & Value $^{1}$ \\
\hline Irrigation system Power & $\mathrm{cv} \mathrm{ha}^{-1}$ & 1.0 \\
Price range for IS acquisition (with and without electric power) & ${\mathrm{US} \$ \mathrm{ha}^{-1}}^{-1}$ & $2.500,00-7.500,00$ \\
Range IS useful life & Years $^{-1}$ & $5.0-15.0$ \\
Time range at IS operation & $\mathrm{h} \mathrm{day}^{-1}$ & $0.5-1.0$ \\
Irrigation time period with reduced power tariff & $\mathrm{h} \mathrm{day}^{-1}$ & 0.0 \\
IS operation period & $\mathrm{Months} \mathrm{year}^{-1}$ & $3.0-5.0$ \\
Fertilizer injection system cost & $\mathrm{U} \mathrm{ha}^{-1}$ & 500.00 \\
Water cost & $\mathrm{U} \mathrm{W} \mathrm{m}^{-3}$ & 0.0 \\
Annual interest rate & $\%$ & 12.0
\end{tabular}

\section{Electric Power Characterization}

\begin{tabular}{|c|c|c|}
\hline Installed power cost & US\$ kw ${ }^{-1}$ & 2.5 \\
\hline Energy consumed cost ${ }^{2}$ & $\mathrm{US} \$ \mathrm{kw}^{-1} \mathrm{~h}^{-1}$ & 0.13972 \\
\hline Electric net acquisition $\operatorname{cost}^{3}$ & $\mathrm{US} \$ \mathrm{~km}^{-1}$ & $3,900.00$ \\
\hline Electric net length & $\mathrm{km}$ & 0.04 \\
\hline Reduction in the energy rate & $\%$ & 70.0 \\
\hline
\end{tabular}

1 - values expressed in dollars and U.S. dollars as of this study $=\$ 1.75$;

2-http://www.rge-rs.com.br/ServiccedilosOnline/Tarifas/tabid/75/language/pt-R/Default.aspx;

3 - 37.5 KVA three-phase network

4 -DNAEE decree 105 of 02 to 08 October 2002 and ANEEL Resolution 207/2006.

Table 2. Average data of 'Itália' table grapes used to study their economic feasibility.

\begin{tabular}{|c|c|c|}
\hline Orchard Characterization & Unit & Value \\
\hline Between-plant spacing & $\mathrm{m}$ & 1.5 \\
\hline Row spacing & $\mathrm{m}$ & 2.5 \\
\hline Range of irrigated area & ha & $1.0-4.0$ \\
\hline Range of yield crop in dry land (between 3 and 6 years of growing) & $\mathrm{Mg} \mathrm{ha}^{-1}$ year $^{-1}$ & $15.0-24.0$ \\
\hline Average sale price by the producer & US\$ $\mathrm{Mg}^{-1}$ & $1,400.00$ \\
\hline Average Reference Evapotranspiration $(\mathrm{ETo})^{1}$ & $\mathrm{~mm}_{\text {day }}{ }^{-1}$ & 1.6 \\
\hline Implementation of the plastic cover cost ${ }^{2}$ & US\$ ha ${ }^{-1}$ & $26,000.00$ \\
\hline Plastic cover useful life & Years & 6.0 \\
\hline
\end{tabular}

1 - Average climatological normal for Bento Gonçalves, http://www.cnpuv.embrapa.br/;

2 - Average data from three quotes obtained from companies operating in the region. 
It was considered for the economic viability of the project, that the net yield of the 'Itália' vineyard grape irrigated or fertilized under plastic cover should be at least equal to the net income of the 'Itália' vineyard grape without irrigation or fertigation and without plastic cover:

$$
P c i=[(P c s \times P p)+C T A] \times P p^{-1}(2)
$$

where $P p$ is the selling price of the product, $\mathrm{US} \mathrm{Mg}^{-1}, C T A$ is the total annual cost of the irrigation and fertigation project, $\mathrm{U} \$ \mathrm{ha}^{-1} \mathrm{year}^{-1}$, calculated by:

$$
C T A=C F A+C V A(3)
$$

where $C V A$ is the variable annual cost and $C F A$ annual fixed cost, both in $\mathrm{U} \$ \mathrm{ha}^{-1} \mathrm{year}^{-1}$ :

$$
C F A=(F R C \times C s i)(4)
$$

Where $C s i$ is the purchase price of the irrigation system or drip irrigation under plastic cover, U\$ $\mathrm{ha}^{-1}, F R C$ is the capital recovery factor given by:

$$
F R C=\left[\left(j \times 100^{-1}\right) \times\left(\left(j \times 100^{-1}\right)+1\right)^{V U}\right] \times\left[\left(\left(j \times 100^{-1}\right)+1\right)^{V U}-1\right]^{-1}(5)
$$

where $j$ is annual interest rate, $\%, V U$ is useful life of the project, years. The cost $C V A$ was given by:

$$
C V A=C e+C m+M o(6)
$$

where $M o$ is the cost of manpower for operating the irrigation and fertigation system, U\$ ha ${ }^{-1}$

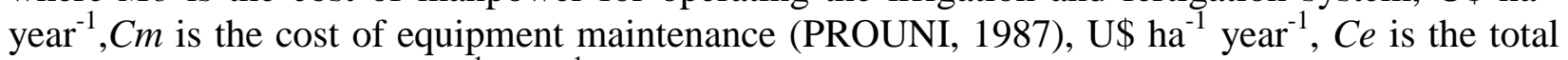
annual cost of energy, $\mathrm{U} \$ \mathrm{ha}^{-1}$ year $^{-1}$, obtained according to Brasil (1988):

$$
C e=F D A+F C A(7)
$$

where FCA is the annual consumption billing and FDA is billing annual demand, both expressed in $\mathrm{U} \$ \mathrm{ha}^{-1}$ year $^{-1}$, given by:

$$
F D A=(12 \times C e i \times P i) \times(1,36)^{-1}(8)
$$

where $C e i$ is the installed energy cost, $\mathrm{U} \$ \mathrm{ha}^{-1}$ year $^{-1}, P i$ is the installed power, $\mathrm{cv} \mathrm{ha}^{-1}$ and:

$$
F C A=30 \times M \times T \times P i \times 1,36^{-1} \times\left[\operatorname{Tr} \times C e c \times\left((100-R t) \times 100^{-1}\right)+(T-T r) \times C e c\right] \times T^{-1}
$$

where $T r$ is the irrigation and fertigation running time in the reduced power tariff period, $\mathrm{h}$ day ${ }^{1}, R t$ is the reduction in the energy rate, $\%, C e c$ is consumed energy cost, $\mathrm{U} \$ \mathrm{~kW}^{-1}$. A sensitivity analysis was performed by means of simulations using electronic spreadsheets in various situations, which varied the irrigation system price, the useful life of the irrigation system, the method of applying water and irrigated or fertigated area.

\section{RESULTS AND DISCUSSION}

The purchase price of the irrigation equipment that is directly related to the quality of material used, the degree of automation of the system and the specific characteristics of each project influenced the parameter in this study suggested that "yield increase was sufficient to sustain the irrigation and plastic cover techniques "(PI) $(\%)$ in 'Itália' table grape production (Figure $1)$. 


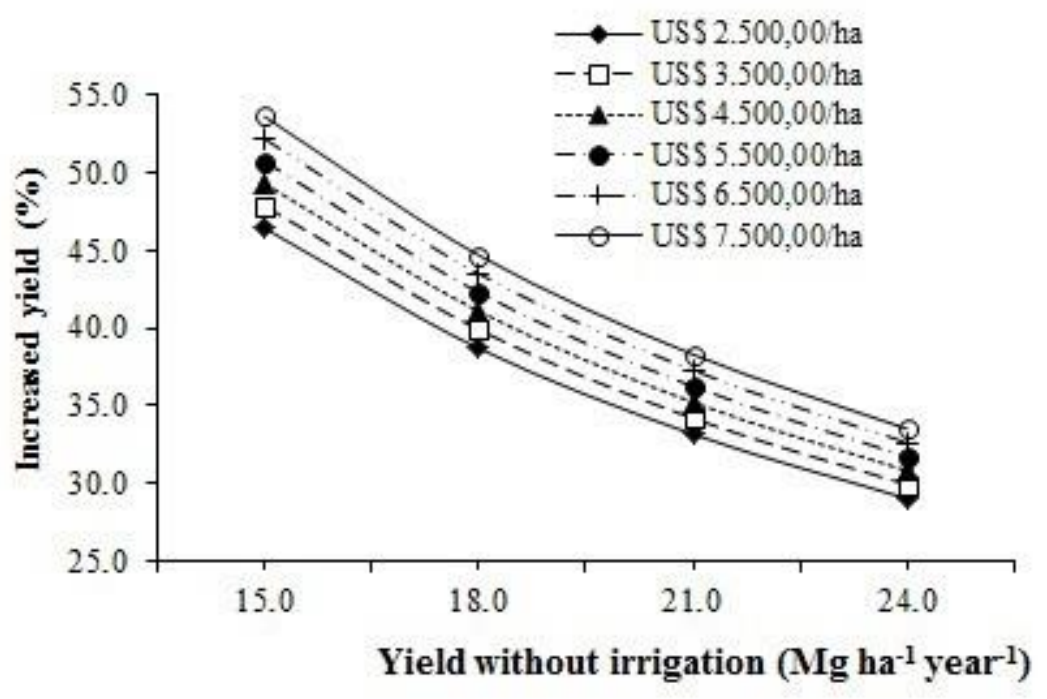

Figure 1. Variation of the need for yield increase under irrigation equipment price.

In yields in the early years of productive culture ( 3 - 6 years growth) without irrigation, as shown in Figure 1, the $I P$ reached values up to $53.7 \%$, i.e. an increase of about $8000 \mathrm{~kg} \mathrm{ha}^{-1}$. This increase was the result of more extreme conditions, i.e., the most expensive irrigation equipment and the crop in the first year of production (corresponding to the 3rd year of growth). However, if probable yield is considered when the crop reaches yield stability (considered in this study as from the 6th year of growth) and the lowest purchase cost, even the highest, the IP becomes relatively moderate, ranging from 29.0 to $33.5 \%$.

Likewise, the life of the irrigation system also influenced the IP. According to Figure 2, the equipment useful life made the IP reach values around $51.0 \%$. Compared to a useful life of 5, with 8 and with 12 years, PIs were 3.3 and $1.8 \%$ higher, respectively. Therefore, this showed that it was not always an economically viable option for lower equipment cost and useful life. Furthermore, it should be considered that a device with a very low price can have poor quality parts, which require frequent maintenance or replacement, with low efficiency and water uniformity, and smaller diameter pipelines, which cause higher load loss and power consumption.

Even with the increase in cost with the adoption of drip irrigation, because of the structure necessary for fertilizer injection and skilled labor for its proper handling, the IP $(\%)$ required to enable the irrigation and plastic cover was lower $(30.4 \%)$ when compared with adopting irrigation and plastic cover $(30.8 \%$ ) (Figure 3) due to reduction in fertilizer costs and the extinction of the workforce for its application. We decided to analyze also the grape fertigated without pumping due to regional topography that is a widespread practice among 'Itália' table grape irrigators (Figure 3). The evaluation showed that in the period of stable production, the IP to enable this condition did not reach $30 \%$. The reduction was not so significant compared with the pumped system, because even in systems that do not need electrical pumping, pipes, fittings, filters, emitters and other parts of the hydraulic network must be purchased, without the need to acquire the 
entire pump and in this case, since it was a localized irrigation system located in topographical conditions which contributed powering the system the costs were low compared to sets of power / area.

Comparing an area of 1 ha of table grape fertigated with plastic cover and the other of 4ha with the same practices, we observed a significant reduction, $27.2 \%$ on average, in the IP (Figure 4). This demonstrated the high profitability of 'Itália' table grape farming, because the increase in net income to increase in area was significantly higher than the increase in total annual costs. The crop at the beginning of productive activity (3rd year of growth), grown on 1 ha, requires an IP of $48.7 \%$ (7300 $\mathrm{kg} \mathrm{ha}^{-1}$ ) to become economically viable and the adoption of drip irrigation and plastic sheeting. In an area of 4 ha, however, this need is reduced to $38.3 \%\left(5700 \mathrm{~kg} \mathrm{ha}^{-1}\right)$ to make the activity economically viable.

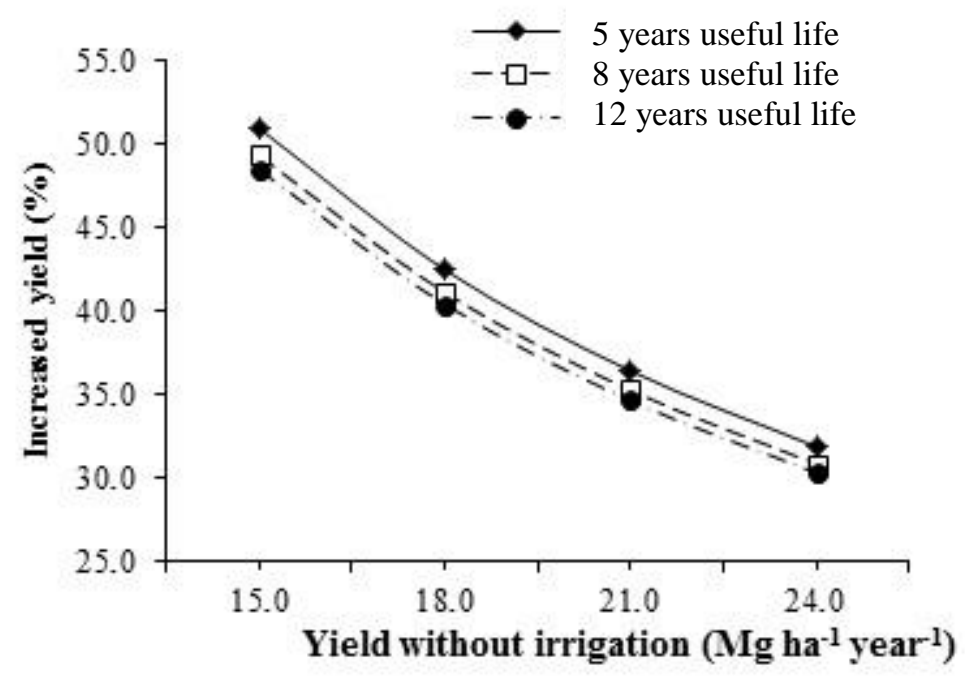

Figure 2. Variation of the need for yield increase under irrigation equipment useful life.

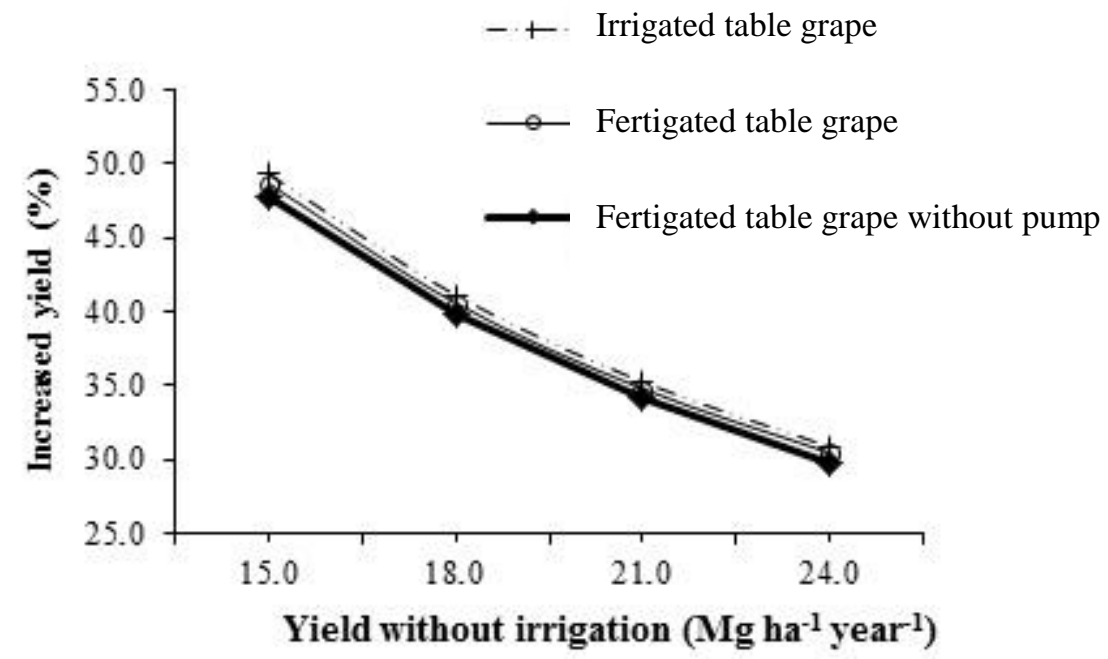

Figure 3. Variation of the need for yield increase of 'Itália' table grapes irrigated, fertigated and fertigated grapes without pumping power. 


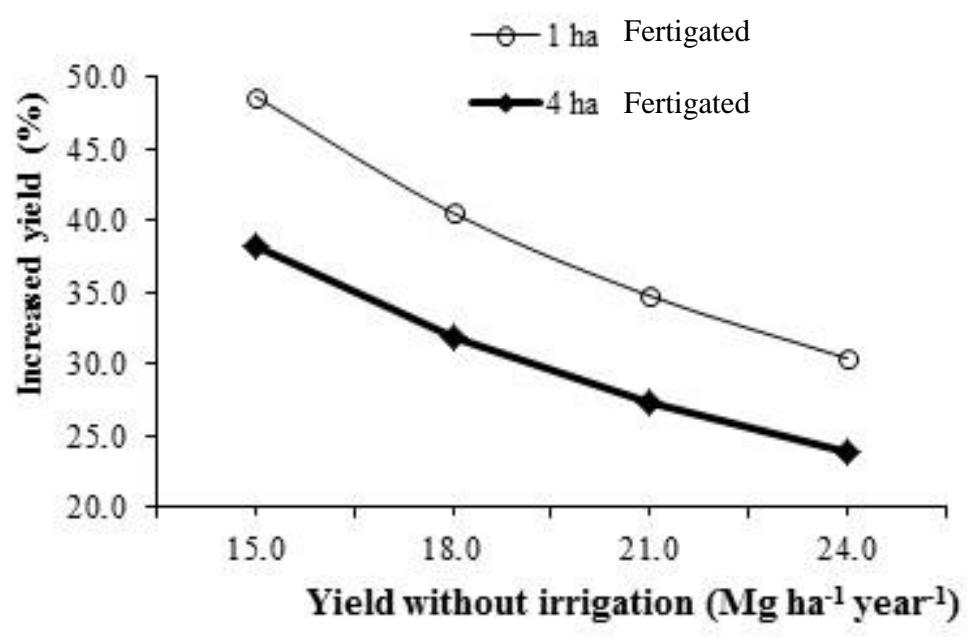

Figure 4. Variation of the need for yield increase for 'Itália' table grapes fertigated under plastic cover, a one ha area compared with 4 ha area.

\section{CONCLUSIONS}

For technical and economic feasibility of IS and FES installation in 'Italy' table grape vine yards under plastic cover to be technically and economically feasible in the Serra Gaúcha region, a yield increase from $29 \%$ (IS low cost, long useful life and installed in the plant production stability phase) to $53.7 \%$ (FES automated, short useful life and installed in the first year of growing crop phase)is needed.

\section{ACKNOWLEDGMENT}

The authors thank FAPERGS (process 10/0228-6) for financial support.

\section{REFERENCES}

BRASIL. 1988. Comitê de Distribuição de Energia Elétrica. Tarifas horosazonais, manual de orientação ao consumidor. Rio de Janeiro: CODI. 28p.

CARPIO, C.; NESMITH, D.S. 2006. Economic Assessment of Irrigation Management in Muscadine Grapes.
HortTechnology, Alexandria, v.16, n.3, p. 478-482.

CHAVARRIA, G.; CARDOSO, L.S.; BERGAMASCHI, H.; SANTOS, H.P. dos; MANDELLI, F.; MARODIN, G.A.B. 2009a. Microclimate of vineyard $\mathrm{S}$ under protected cultivation. Ciência Rural, Santa Maria, v.39, n.7, p.20292034.

CHAVARRIA, G.; SANTOS, H.P. dos; MANDELLI, F.; MARODIN, G.A.B.; BERGAMASCHI, H.; CARDOSO, L.S. 2009b. Yield potential of grape vine cultivated under plastic cover. Pesquisa Agropecuária Brasileira, Brasília, v.24, n.2, p.141-147.

COMPANHIA NACIONAL DO ABASTECIMENTO (CONAB). Normas específicas de uva industrial - safra 2008/2009. Available from: <http://www.conab.gov.br/conabweb/do wnload/precos_minimos/proposta_de_pr ecos_minimos_safra_2007_08_uva_indu strial.pdf>. Acessed: 02 Set. 2009.

CONCEIÇÃO, M.A.F. 2008. A irrigação na produção de uvas para elaboração de vinhos finos. Bento Gonçalves: 
Embrapa Uva e Vinho. 20p. (Embrapa

Uva e Vinho. Circular Técnico, 79).

EMBRAPA UVA E VINHO. Dados meteorológicos. Available from: <http://www.cnpuv.embrapa.br/>. Acessed: 03 Set. 2009.

EZZHAOUANI, A; VALANCOGNE, C.; PIERI, P.; AMALAK, T.; GAUDILLÈRE, J. 2007.Water economy by Italia grapevines under different irrigation treatments in a Mediterranean climate. International Journal of Vine and Wine Sciences, Villenaved'Ornon, v.41, n.3, p.131-139.

MANETA, M.P.; TORRES, M.; WALLENDER, W.W.; VOSTI, S.; KIRBY, M.; BASSOI, L.H.; RODRIGUES, L.N. 2009. Water demand and flows in the São Francisco River Basin (Brazil) with increased irrigation. Agricultural Water Management, v.96, n.8, p.1191-1200.

MOTA, C.S.; AMARANTE, C.V.T. do; SANTOS, H.P. dos; ZANARDI, O.Z. 2008. Vegetative growth and yield of 'Cabernet sauvignon' grapevine under overhead plastic covering.Revista Brasileira de Fruticultura, Jaboticabal, v.30, n.1, p.148-153.

NAMARA, R.E.; NAGAR, R.K.; UPADHYAY, B. 2007. Economics, adoption determinants, and impacts of micro-irrigation technologies: empirical results from India. Irrigation Science, v.25, n.3, p.283-297.

OZKAN, B.; FERT, C.; KARADENIZ, F. 2006. Energy and cost analysis for greenhouse and open-field grape production. Energy, Antalya, v.32, n.8, p.1500-1504.

DNAEE. 2002. Portaria do Departamento Nacional de Águas e Energia Elétrica, $\mathrm{n}^{\circ} 105$ of october 2002 . .

PRONI - PROGRAMA NACIONAL DE IRRIGAÇÃO. 1987. Tempo de irrigar: manual do irrigante. São Paulo: Mater, Fundação Victor Civita. 160 p.
WILSON, P. 2001. First-order economizing: irrigation technology adoption and the farm. Agrekon, Agricultural Economics Research, Policy and Practice in Southern Africa, Arcadia, v.40, n.2, p.231-248.

TEIXEIRA, A.H.C.; BASTIAANSSENC, D.; BASSOI, L.H. 2007. Crop water parameters of irrigated wine and table grapes to support water productivity analysis in the São Francisco river basin, Brazil. Agricultural Water Management, v.94, n.1-3, p.31-42.

VILELA, O.C.; BIONE, J.; FRAIDENRAICH, N. 2004. Simulation of grape culture irrigation with photovoltaic V-trough pumping systems. Renewable Energy, v.29, n.10, p.16971705.

Recebido em: 25/03/2013 Aceito para publicação em: 27/11/2013 